\title{
Intimate Partner Violence and Gender A/Symmetry: An Integrative Literature Review
}

\author{
Josiane Razera - Faculdade Meridional \\ Icaro Bonamigo Gaspodini - Faculdade Meridional (IMED) \\ Denise Falcke - Pontifícia Universidade Católica do Rio Grande do Sul, Porto Alegre, Brasil
}

\begin{abstract}
Gender stereotypes have largely been discussed in the occurrence of marital violence, mainly in international literature. The objective was to map and analyze scientific literature, published between 2010 and 2015, using the databases ISI Web of Science, Academic Search Complete, Medline Complete, PsycInfo e Scielo. Strings used were: a) first search strategy - "intimate partner violence" AND "gender symmetry"; b) second search strategy - "intimate partner violence" AND "gender asymmetry". We analyzed 48 journal articles entirely available online. Most publications are from The United States $(60.41 \%)$ and use quantitative research designs $(60.41 \%)$. The most frequently used instrument was the Revised Conflict Tactics Scales (CTS2), even though criticized because of its checklist structure. Disagreement remains about gender a/symmetry in conjugal violence, however, an emerging perspective affirms that these cases should not be generalized and each couple's specificities must be assessed. National studies are necessary to contemplate different aspects of this phenomenon.

Keywords: symmetry; asymmetry; gender; conjugal relationships; intimate partner violence
\end{abstract}

\section{Violência entre Parceiros Íntimos e As/simetria de Gênero: Revisão Integrativa da Literatura}

\begin{abstract}
Resumo
Estereótipos de gênero têm sido bastante discutidos na ocorrência de violência conjugal, principalmente na literatura internacional. Objetivou-se mapear e analisar a literatura científica, publicada entre os anos de 2010 e 2015, nas bases: ISI Web of Science, Academic Search Complete, Medline Complete, PsycInfo e SciELO. Empregou-se os descritores: a) primeira estratégia de busca - "intimate partner violence" AND "gender symmetry"; b) segunda estratégia de busca - "intimate partner violence" AND "gender asymmetry". Foram analisados 48 artigos disponíveis na íntegra. Predominaram as publicações realizadas nos Estados Unidos (60,41\%), preponderantemente de delineamento quantitativo (60,41\%). O instrumento mais utilizado foi a Revised Conflict Tactics Scales (CTS2), embora criticada por se tratar de uma escala do tipo checklists. Ainda existem discórdias acerca da as/simetria de gênero na violência conjugal, porém surge uma perspectiva que defende a não generalização desses casos e considera fundamental avaliar as particularidades de cada casal. Estudos nacionais são necessários para contemplar as diferentes facetas desse fenômeno. Palavras-chave: simetria, assimetria, gênero, relações conjugais, violência entre parceiros íntimos
\end{abstract}

\section{Violência Marital y As/simetría de Género: Una Revisión Integradora de la Literatura}

\begin{abstract}
Resumen
Los estereotipos de género han sido ampliamente discutidos en la ocurrencia de violencia conjugal, sobre todo en la literatura internacional. Se objetivó mapear y analizar la literatura científica publicada entre los años 2010 a 2015, en las bases: ISI Web of Science, Academic Search Complete, Medline Complete, PsycINFO y Scielo. Se emplearon los descriptores: a) primera estrategia de búsqueda - "intimate partner violence" AND "gender symmetry”; b) segunda estrategia de búsqueda - "intimate partner violence" AND "gender asymmetry". Fueron analizados 48 artículos disponibles en su totalidad. La mayoría de los publicaciones se realizaron en Estados Unidos (60,41\%), principalmente de delineamiento cuantitativo (60,41\%). El instrumento más utilizado fue la Revised Conflict Tactics Scales (CTS2), aunque fue criticado por tratarse de una escala de tipo checklists. Todavía existen desacuerdos sobre las as/simetría de género en violencia conjugal, sin embargo, en la actualidad surge una perspectiva que defiende la no generalización de esos casos y considera que es fundamental evaluar las particularidades de cada pareja. Se necesitan estudios nacionales para contemplar las diferentes fases de este fenómeno.

Palabras-clave: simetría; asimetría; género; relaciones conjugales; violencia de pareja.
\end{abstract}

\section{Introduction}

The concept of gender emerged in the late 1940s with the research of John Money, a psychologist who worked with surgery and hormone therapy for individuals then called hermaphrodites (Cyrino, 2013). Although Money had considered the social construction of gender (Butler, 2006), it is only since the 1970s that the movement and feminist theory embraced the concept as a size analysis of the society and unequal relations between men and women (Mayorga, Coura, Miralles, \& Cunha, 2013). This milestone allowed an understanding of the differences between male and female as no longer static and immutable (Santos \& Izumino, 2005).

The American Psychological Association (APA) defines biological sex as the chromosomal, gonadal, reproductive and genital characteristics of male and 
female phenotypes (APA, 2011). Gender, in turn, refers to the attitudes, feelings and behaviors that a particular culture associates with sex, that is, the normality of gender depends on the cultural expectations of male and female roles (APA, 2011). Thus, the notion of gender posits a construction of meanings made from psychological, social and cultural characteristics, in addition to the biological dimension referred to as sex (Days \& Machado, 2008).

The gender asymmetry, seen as inequality between men and women, reveals differences in the performance of social, cultural and family roles. To masculinity, are assigned the duties of manhood, strength and a position of power in relationships. On the other side, on the female universe, is expected the practice of motherhood, care of children / household. It is expected that men and women engage in different tasks, which distance each other in terms of reason and emotion, respectively. However, even if one sees benefits in the social hierarchy of genres, it is often framed in certain social and cultural models that, if breached can cause pain (Guedes, Silva, \& Coelho, 2007; Krishnan et al., 2012; Oliveira \& Souza, 2006).

The sizeable impact of these differences motivates various studies in the genre issue, especially in regards to its combination with the occurrence of violence in marital relationships. Some cross-cultural studies show that the socially constructed differences between female and male put women at a disadvantage in relation to men (Guedes et al., 2007, Lamoglia \& Minayo, 2009), reinforcing feminist currents which understand that the fragility of a woman in relation to a man characterizes domestic violence mostly as gender violence, expressed in one way - offender man and victim woman (Gomes Diniz, Araújo \& Coelho, 2007; Pazo \& Aguiar, 2012). From this perspective, although men and women can commit acts of violence, there are significant differences in manner and intensity, being the woman the most debilitated (Lee, Stefani, \& Park, 2014).

In contrast, another line of theory understands that blaming the men (and consequent victimization of women) may reinforce the distinction between genders (Falcke, Olive, Pink, \& Bentancur, 2009; Straus, 2008). The need to look at the marital relationship, which is dynamic and not static, leads to perceive couples in violent relationships as co-authors of the marital history. Thus, male or female, both can suffer or perpetrate any form of violence in the marital relationship. Studies have reported similar levels of perpetration and victimization of violence between men and women (Fortin,
Guay, Lavoie, Boisvert, \& Beaudry, 2012; Gomez \& Montesino, 2014), which leads to think that domestic violence can take on a bias that takes gender symmetry into consideration (Straus, 2008) and where marital violence is understood as an interactional phenomenon (Alvim \& Souza, 2005; Falcke et al., 2009; Williams \& Frieze, 2005).

There is controversy and lack of consensus in the scientific literature regarding how the gender influences the occurrence of intimate partner violence between spouses, which brings out the need to investigate the issue. The goal of this paper was to map and analyze the scientific literature published between the years 20102015, about intimate partner violence and gender as/ symmetry, taking into consideration the goal, method, sample characteristics and the instruments used, as well as the main study results.

\section{Method}

For this integrative literature review (Mendes Silveira, \& Galvão, 2008), we carried out searches on articles indexed in five databases: ISI Web of Science, Academic Search, Medline Complete, PsycInfo and Scielo. In order to locate articles that addressed the issues related to domestic violence and gender a/symmetry, two strategies have been carried out, with the following descriptors and Boolean operator: a) first strategy - "intimate partner violence" AND "gender symmetry "; b) second strategy - "intimate partner violence" AND "gender asymmetry". We opted to search for the descriptors in English language because the research in Portuguese had no results.

The inclusion criteria were: online articles, complete, unpaid, published in the years between 2010 and 2015. Reviews, books, theses and dissertations were excluded. Then we scanned for duplicated articles between bases and also between the two searches with different descriptors. Seeking greater data reliability, the search was carried out by two independent researchers. If there was disagreement, a third researcher would have been consulted (Zoltowski, Costa, Teixeira \& Koller, 2014), however, this was not necessary. In all, 113 articles were found, of which 81 were drawn from the bases after application of the inclusion criteria. After the exclusion of repeated and not fully available, 53 articles were selected for reading and content analysis, on which the categories were defined a posteriori (Bardin, 1977). The flowchart in Figure 1 illustrates the strategy used: 


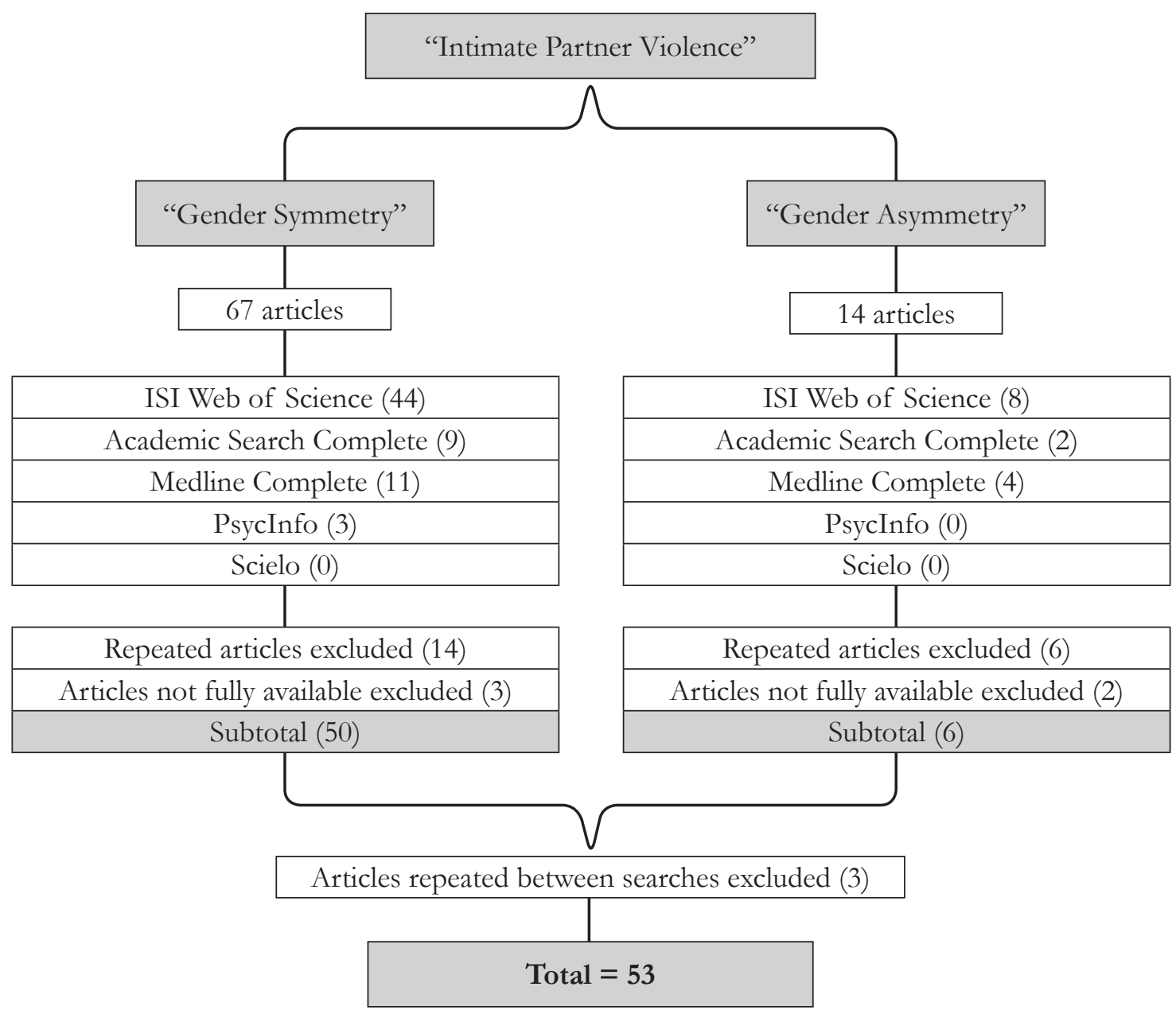

Figure 1. Flowchart

\section{Results}

Upon reading the articles, we found that, in regard to the country of origin of the study, the majority (58.49\%) comes from the United States (31 articles). Following the distribution, the production came from the United Kingdom (5), Sweden (4), international studies (3), Australia (2), China (2), Canada (1), Ecuador (1), Israel (2) Slovenia (1) and Ireland (1). All were written in English and none were from Brazil.

Varied proposals were identified in the objectives of the articles, however, all of them dealt with the different manifestations of violence and its consequences on the health of those involved. For some, the predominant was a theoretical research of controversies existent in the literature on gender a/symmetry (Chan, 2011; Enander, 2011; Hamby, 2015; LanghinrichsenRohling, 2010; Stark, 2010; Winstok, 2015). In other cases, the influence of male and female in different models of relationships was analyzed: in heterosexual individuals (Marshall, Jones, \& Feinberg, 2011), homosexual couples (Messinger, 2011), married (Chan, 2012), separated (Johnson, Leone, \& Xu, 2014) or dating (Hamby \& Turner, 2013; Volpe, Hardie, \& Cerulli, 2012). Another highlight for the goals was the interest in validating (Lehmann, Simmons, \& Pillai, 2012) or exploring (Nybergh, Taft, \& Krantz, 2012) instruments, as well as to answer the questions made on the validity of the Conflict Tactics Scale (CTS) or the Revised Conflict Tactics Scale (CTS2) (Straus, 2012).

Regarding the methodological outline, we found different results, as shown in Table 1.

We found that 32 studies used data collection instruments, of which $15(46.87 \%)$ worked with the CTS or CTS2, or specific subscales of these instruments (Ackerman, 2012; Bates, Graham-Kevan, \& Archer, 
Table 1

Articles distributed by research outline

\begin{tabular}{lcc}
\hline Outline & Number of Articles & Percentage \\
\hline Literature Review/ Theorical & 18 & $33.96 \%$ \\
Quantitative (explanatory) & 14 & $26.41 \%$ \\
Quantitative (exploratory) & 10 & $18.86 \%$ \\
Quantitative (descriptive) & 06 & $11.32 \%$ \\
Qualitative & 02 & $3.77 \%$ \\
Mixed & 02 & $3.77 \%$ \\
Method Development & 01 & $1.88 \%$ \\
\hline
\end{tabular}

2014; Chan, 2012; Jaquier \& Sullivan, 2014; Johnson et al., 2014; Leonard, Winters, Kearns-Bodkin, Homish, \& Kubiak, 2014; Lövestad \& Krantz, 2012; Marshall et al., 2011; Renner, Habib, Stromquist, \& Peek-Asa, 2014; Sillito, 2012; Sullivan et al., 2010; Volpe et al., 2012; Zanoni, Warburton, Bussey, \& McMaugh, 2014). Other instruments used for the investigation of domestic violence were: Relationship Behavior Rating Scale (RBRS); Ineffective Arguing Inventory; The Relationship Attribution Measure; Personal and Relationship Profile; Domestic Violence Screening Instrument Revised; Male Role Norms Inventory-Revised; Hostile Sexism scale; Dominance Scale; Richardson Conflict Response Questionnaire; WHO's Violence Against Women. In cases where the objective was the investigation of domestic violence from the perspective of children and adolescents, the following instruments were used: Childhood Exposure to Domestic Violence Scale; Past Abusive Behavior Inventory; Juvenile Victimization Questionnaire; Conflict in Adolescent Dating Relationships Inventory. For the investigation of coercive behaviors: Yllo's Controlling Behavior Questions; CCB (Checklist of Controlling Behaviors); Coercive Control Scale; Controlling Behavior Scale; Hostile Control and Control; Sexual Relationship Power Scale. The authors also used other data collection techniques such as individual interviews, focus groups, life history and document analysis.

In regard to the characteristics of participants / samples of the studies, 22 empirical studies used women and men. Of the studies that used women and men, only five conducted their research with couples (Chan, 2012; Leonard et al., 2014; Marshall et al., 2011; Renner et al., 2014; Tanha, Beck, Figueredo, \& Raghavanet, 2010). Seven studies used a sample composed only of women (Goicolea, Öhman, Torres, Morras,
\& Edin, 2012; Jaquier \& Sullivan, 2014; Lehmann et al., 2012; Messinger, 2011; Simmons, Farrar, Frazer, \& Thompson, 2011; Sullivan et al., 2010; Volpe et al., 2012). Finally, three studies used an exclusively male sample (Nybergh et al., 2012; Whitaker, 2013; Zanoni et al., 2014).

The results showed the different perceptions about the discussion of symmetry and asymmetry of gender and the controversies generated by this dilemma in the literature. An analysis revealed six distinct categories of results, as shown in Table 2 .

1) Studies show that both men and women can be perpetrators in situations of violence, however levels differ depending on the subtypes of violence (Bates et al., 2014; Chan, 2012; Corbally, 2015; Hamby \& Turner, 2013; Johnson et al., 2014; Lövestad \& Krantz, 2012; Melander, Noel, \& Tyler, 2010; Myhill, 2015; Post, Mezey, Maxwell, \& Rhodes, 2011; Tanha et al., 2010), which needs to be taken into account planning interventions (Allen, 2011; Brown, 2012; LanghinrichsenRohling, 2010; Stark, 2010). Also, violence tends to start asymmetrically and becomes symmetrical with time (Leonard et al., 2014).

2) Studies that emphasize the relevance of gender in domestic violence (Dragiewicz \& DeKeseredy, 2012; Enander, 2011; Gerstenberger \& Williams, 2013; Hamby, 2014; Johnson, 2010; Umubyeyi, Mogren, Ntaganira, \& Krantz, 2014) and show that there are differences between genders in the understanding of the phenomenon. A quantitative study was conducted in the United States to check whether child custody evaluations are affected or not by the statements of judges and lawyers 
Table 2

Summary of the results of the analysed studies

\begin{tabular}{|c|c|c|c|}
\hline Category & Content & $\begin{array}{l}\text { Number } \\
\text { of Articles }\end{array}$ & Articles \\
\hline 1 & $\begin{array}{l}\text { Men and women can be } \\
\text { perpetrators in situations of } \\
\text { violence, however, the levels } \\
\text { vary according to the subtypes } \\
\text { of violence }\end{array}$ & 15 & $\begin{array}{l}\text { Allen, 2011; Bates, Graham-Kevan, \& Archer, 2014; } \\
\text { Brown, 2012; Chan, 2012; Corbally, 2015; Hamby } \\
\text { \& Turner, 2013; Johnson, Leone, \& Xu, 2014; } \\
\text { Langhinrichsen-Rohling, 2010; Leonard, Winters, } \\
\text { Kearns-Bodkin, Homish, \& Kubiak, 2014; Lövestad \& } \\
\text { Krantz, 2012; Melander, Noel, \& Tyler, 2010; Myhill, } \\
\text { 2015; Post, Mezey, Maxwell, \& Rhodes, 2011; Stark, } \\
\text { 2010; Tanha, Beck, Figueredo, \& Raghavanet, } 2010\end{array}$ \\
\hline 2 & $\begin{array}{l}\text { Gender asymmetry and marital } \\
\text { violence }\end{array}$ & 8 & $\begin{array}{l}\text { Cross, Tee, \& Campbell, 2011; Dragiewicz \& } \\
\text { DeKeseredy, 2012; Enander, 2011; Gerstenberger } \\
\text { \& Williams, 2013; Hamby, 2014; Hans, Hardesty, } \\
\text { Haselschwerdt, \& Frey, 2014; Johnson, 2010; } \\
\text { Umubyeyi, Mogren, Ntaganira, \& Krantz, } 2014\end{array}$ \\
\hline 3 & $\begin{array}{l}\text { Gender symmetry in marital } \\
\text { violence }\end{array}$ & 8 & $\begin{array}{l}\text { Carlyle, Scarduzio, \& Slater, 2014; Chan, 2011; } \\
\text { Fincham, Cui, Gordon, \& Ueno, 2013; Marshall, Jones, } \\
\text { \& Feinberg, 2011; Sullivan et al., 2010; Walsh et al., } \\
\text { 2010; Winstok, 2013; Zanoni, Warburton, Bussey, \& } \\
\text { McMaugh, } 2014\end{array}$ \\
\hline 4 & $\begin{array}{l}\text { Explanation of differences } \\
\text { in feminist studies and other } \\
\text { approaches }\end{array}$ & 2 & $\begin{array}{l}\text { Bumiller, 2010; Goicolea, Öhman, Torres, Morras, \& } \\
\text { Edin, } 2012\end{array}$ \\
\hline 5 & $\begin{array}{l}\text { Investigation of factors that } \\
\text { predict marital violence }\end{array}$ & 12 & $\begin{array}{l}\text { Ackerman, 2012; Caldwell, Swan, \& Woodbrown, } \\
\text { 2012; Jaquier \& Sullivan, 2014; Melander et al., 2010; } \\
\text { Messinger, 2011; Nybergh, Taft, \& Krantzet, 2013; } \\
\text { Nowinski \& Bowen, 2011; Renner, Habib, Stromquist, } \\
\text { \& Peek-Asa, 2014; Selic, Svab, \& Gucek, 2014; Sillito, } \\
\text { 2012; Volpe, Hardie, \& Cerulli, 2012; Whitaker, } 2013\end{array}$ \\
\hline 6 & $\begin{array}{l}\text { Various themes and instrument } \\
\text { validation }\end{array}$ & 6 & $\begin{array}{l}\text { Lehmann, Simmons, \& Pillai, 2012; Messinger, Fry, } \\
\text { Rickert, Catallozzi, \& Davidson, 2014; Miller, Cater, } \\
\text { Howell, \& Graham-Bermann, 2014; Nybergh, Taft, \& } \\
\text { Krantz, 2012; Simmons, Farrar, Frazer, \& Thompson, } \\
\text { 2011; Straus, } 2012\end{array}$ \\
\hline
\end{tabular}

on the occurrence of domestic violence. Clinical vignettes were presented to men and women and there was difference in the understanding of the data. Upon reading, men were $60 \%$ more likely to perceive mutual assault allegations, while women demonstrated being up to $40 \%$ more likely to understand unidirectional aggression (Hans, Hardesty, Haselschwerdt, \& Frey, 2014). Men tend to inhibit their aggressiveness when with their partners, not because they are their partners, but 
because they are women, while women increase their aggressiveness with partners, not because they are men, but because they are their partners (Cross, Tee, \& Campbell, 2011).

3) Studies that show similarity in female and male perpetration, revealing gender symmetry in domestic violence (Carlyle, Scarduzio, \& Slater, 2014; Chan, 2011; Fincham Cui, Gordon, \& Ueno, 2013; Marshall et al., 2011; Sullivan et al., 2010; Walsh et al., 2010; Winstok, 2013; Zanoni et al, 2014).

4) Articles that meditate on the differences in feminist and family studies (Goicolea et al., 2012), understanding that the feminist explanatory framework, failing to contribute to the theory and practice, made room for the triumph of "gender neutral" approaches (Bumiller, 2010).

5) Researches that investigated predictors of marital violence, such as education, depression and drug use (Melander et al., 2010), bisexuality (Messinger, 2011), social support, growing up with domestic violence and not being married (Nybergh, Taft, \& Krantz, 2013); ethnicity and homosexuality (Nowinski \& Bowen, 2011); power and control (Caldwell, Swan \& Woodbrown, 2012; Volpe et al., 2012; Whitaker, 2013), education and unemployment rates (Selic, Svab, \& Gucek, 2014) and post-traumatic stress disorder (Jaquier \& Sullivan, 2014). In the same line, some investigated predictors of violence, such as depressive symptoms (Renner et al., 2014), marital dissatisfaction and divorce (Ackerman, 2012), worse physical health, depression and fear in female victims and not in male victims (Sillito, 2012).

6) Articles that addressed diverse topics associated with the gender a/symmetry and proved the validity of instruments for measuring violence (Lehmann et al., 2012; Straus, 2012), the influence of family origin (Miller, Cater, Howell, \& Graham-Bermann, 2014), strategies to increase the search for help (Simmons et al., 2011), that violence in intimate relationships between adolescents differs from that seen in adults (Messinger, Fry, Rickert, Catallozzi, \& Davidson, 2014) and that boundaries between acts of psychological, physical and sexual violence were indistinct among the men exposed to domestic violence (Nybergh et al., 2012).
Although there are different perspectives, researchers alert that the assumption that violence is symmetrical or asymmetrical can lead to the practice of dangerous interventions that instead of reducing the levels of violence would cause the opposite effect (Allen, 2011). Different types of violence require different types of interventions, and no single factor explains all sorts of intimate partner violence (Brown, 2012; Johnson, 2010; Keating, 2015; Langhinrichsen-Rohling, 2010; Stark, 2010; Straus, 2012). Criticizing this thought, Caldwell et al. (2012) report that the effects of violence are not equal and that women suffer more, especially in terms of injuries, fear and post-traumatic stress. With this in mind, studies suggest assessing the consequences of violence, and not only its manifestations, when planning interventions (Renner et al., 2014; Sillito, 2012).

\section{Discussion}

The systematic review enabled the mapping of productions on gender a/symmetry in domestic violence, considering country of origin of the studies, characteristics of sample and tools, outlines and results. It was found that, especially in the studies of quantitative design, most of the researches used the CTS and / or CTS2 to measure the perpetration and victimization of domestic violence. This instrument consists of 78 items that describe possible actions of the respondent and, reciprocally, of their partner. It has five subscales that assess: 1) physical violence; 2 ) psychological aggression; 3) sexual coercion; 4) injury and 5) negotiating. Each dimension is divided into grave and minor, to assess the severity of the acts of violence. In Brazil, this instrument was validated by Moraes, Hasselmann, \& Reichenheim (2002). The researches using the scale, mostly obtained results that showed a tendency to gender symmetry. Criticizing this, Hamby (2014) points out that self-reported methods such as the CTS have very disparate results in comparison to other investigations. These instruments, or just checklists, do not represent the majority of data on intimate partner violence.

Gender symmetry is found, as believes Chan (2011), especially in cases in which contexts, reasons and consequences of violence are not evaluated. It is recommended that large databases of criminological data and public health be investigated using other measures (Hamby, 2014). In response to these criticisms, Straus (2012), author of the CTS and CTS2 said 
that this criticism of the results that show gender symmetry comes from the theory that puts in check the values of "patriarchal domination." Used worldwide, the CTS2 has high levels of validity and reliability, including in a national (Brazilian) study (Bolze, Crepaldi, Schmidt \& Vieira, 2013). The need for different instruments is evident for evaluation of violence in men and women, to include quantitative and qualitative paradigms.

The investigated population, men and / or women, also allows us to question the different results that were found. Some suggest that women are at a disadvantage and often suffer more violence than men (Caldwell et al., 2012), while others report that no significant differences were found when distinguishing by gender (Bates et al., 2014), and others still, mention differences in the types of violence perpetrated by men and women (Johnson et al., 2014). Of the seven studies that evaluated only women, some bothered to perform analyzes that investigate potential predictors of victimization in domestic violence, noting that women who have suffered some form of abuse in the past were more likely to suffer domestic violence. In articles that had men as participants, the search for control of the relationship led to the physical violence perpetrated by them and partly to sexual coercion, but was not related to psychological violence (Whitaker, 2013). Only four articles (Leonard et al., 2014; Marshall et al., 2011; Renner et al., 2014; Tanha et al., 2010) looked to assess couples. The analysis of the marital set revealed that both men and women report victimization and perpetration of violence. Moreover, it was found that there was gender symmetry in the perpetration of violence, but differences in its frequency. In the same angle, a comprehensive study presented by Razera, Mosmann and Falcke (2016) found that men committed significantly more sexual coercion, while women perpetrated more psychological violence, which could be linked to sociocultural issues. While there may be differences between the types of violence committed, to separately examine the victims and perpetrators may be a bias that influences the results, so it is relevant to do further research and assess this duo.

There are studies that identify with the feminist perspective evaluation of violence, characterizing the asymmetry of gender (Gomes et al., 2007, Pazo \& Aguiar, 2012), as well as others that show a relational perspective and symmetry in the relations (Fortin et al., 2012; \& Gómez Montesino, 2014, Straus, 2008). Beside the two approaches mentioned, another trend brings some controversy about this theoretical gap, seeking to relativize many aspects of asymmetry, such as that of gender symmetry (Langhinrichsen-Rohling, 2010). In this latter perspective, an extensive look at the phenomenon is built up, understanding it from the different manifestations of violence in marriage and proposing to do less of general and more of individualized analysis (Casimiro, 2008). The central premise is to think of the mental health of these spouses and not to find victims and / or perpetrators.

\section{Final Considerations}

This systematic literature review identified the lack of Brazilian studies that address gender symmetry or asymmetry, within these search and inclusion criteria. In addition, it highlights the need for studies that propose to carry out investigations with the marital duo, since most evaluate men or women, usually under the perspective of victims and perpetrators. Although this proposal is bold, the results could contribute to more effective intervention practices in which it would be possible to work together with the spouses on different ways of resolving conflict, improving communication of the couple, as well as training them to identify the main triggers of violence and how to anticipate them.

It is believed that a wide look could assist in understanding the phenomenon, which due to its complexity and various aspects that may be linked to the occurrence of violence. Extremist perspectives can strengthen the phenomenon of violence when blaming one or both spouses for what happened, without regard to the uniqueness of each case.

One possible limitation of this article is that the grouped descriptors may have restricted the search, although they were intended to bring the maximum results of the proposed theme. Further studies with different methodological proposals can contribute to the scientific development of this area, which still needs attention. Only so one can then think of proposals for effective interventions to reduce the suffering of the people involved in domestic violence contexts.

\section{References}

Ackerman, J. M. (2012). The relevance of relationship satisfaction and continuation to the gender symmetry debate. Journal of Interpersonal Violence, 27(18), 3579-3600. doi:10.1177/0886260512447579 
Allen, M. (2011). Is there gender symmetry in intimate partner violence? Child \& Family Social Work, 16(3), 245-254. doi:10.1111/j.1365-2206.2010.00735.x

Alvim, S. F., \& Souza, L. (2005). Violência conjugal em uma perspectiva relacional: homens e mulheres agredidos/agressores. Psicologia: Teoria e Prática, 7(2), 171-206. Retrieved from: http://editorarevistas.mackenzie.br/index.php/ptp/article/ view/1041/759

American Psychological Association. (2011). Definition of terms: Sex, gender, gender identity, sexual orientation. Washington, DC: Author. Retrieved from: http:// www.apa.org/pi/lgbt/resources/sexuality-definitions.pdf

Bardin, L. (1977). Análise de conteúdo. Lisboa, Portugal: Edições 70.

Bates, E. A., Graham-Kevan, N., \& Archer, J. (2014). Testing predictions from the male control theory of men's partner violence. Aggressive Behavior, 40(1), 42-55. doi:10.1002/ab.21499

Bolze, S. D. A., Crepaldi, M. A., Schmidt, B., \& Vieira, M. L. (2013). Relacionamento conjugal e táticas de resolução de conflito entre casais. Actualidades en Psicologia, 27(114), 71-85. Retrieved from: http:// revistas.ucr.ac.cr/index.php/actualidades/article/ view/4828

Brown, J. (2012). Male perpetrators, the gender symmetry debate, and the rejection-abuse cycle implications for treatment. American Journal of Men's Health, 6(4), 331-343. doi:10.1177/1557988312439404

Bumiller, K. (2010). The nexus of domestic violence reform and social science: From instrument of social change to institutionalized surveillance. $A n$ nual Review of Law and Social Science, 6, 173-193. doi:10.1146/annurev-lawsocsci-102209-152813

Butler, J. (2006). Deshacer el género. Barcelona: Paidós.

Caldwell, J. E., Swan, S. C., \& Woodbrown, V. D. (2012). Gender differences in intimate partner violence outcomes. Psychology of Violence, 2(1), 42-57. doi: $10.1037 / \mathrm{a} 0026296$

Carlyle, K. E., Scarduzio, J. A., \& Slater, M. D. (2014). Media portrayals of female perpetrators of intimate partner violence. Journal of Interpersonal Violence, 29(13), 2394-2417. doi: $10.1177 / 0886260513520231$
Casimiro, C. (2008). Violências na conjugalidade: A questão da simetria do gênero. Análise Social, (188), 579-601. Retrieved from: http://analisesocial.ics. ul.pt/documentos/1222271301F5hRJ2yz1Oz55 WJ0.pdf

Chan, K. L. (2011). Gender differences in self-reports of intimate partner violence: A review. Aggression and Violent Behavior, 16(2), 167-175. doi:10.1016/j. avb.2011.02.008

Chan, K. L. (2012). Gender symmetry in the self-reporting of intimate partner violence. Journal of Interpersonal Violence, 27(2), 263-286. doi:10.1177/0886260511416463

Corbally, M. (2015). Accounting for intimate partner violence: A biographical analysis of narrative strategies used by men experiencing IPV from their female partners. Journal of Interpersonal Violence, 30(17), 3112-3132. doi:10.1177/0886260514554429

Cross, C. P., Tee, W., \& Campbell, A. (2011). Gender symmetry in intimate aggression: An effect of intimacy or target sex? Aggressive Behavior, 37(3), 268-277. doi:10.1002/ab.20388

Cyrino, R. (2013). A produção discursiva e normativa em torno do transexualismo: Do verdadeiro sexo ao verdadeiro gênero. Crítica e Sociedade, 3(1), 92108. Retrieved from: http://www.seer.ufu.br/ index.php/criticasociedade/article/view/19727

Dias, A. R. C., \& Machado, C. (2008). Género e violência conjugal: Uma relação cultural. Análise Psicológica, 26(4), 571-586. Retrieved from: http:// www.scielo.mec.pt/pdf/aps/v26n4/v26n4a04.pdf

Dragiewicz, M., \& DeKeseredy, W. S. (2012). Claims about women's use of non-fatal force in intimate relationships: A contextual review of Canadian research. Violence against Women, 18(9), 1008-1026. doi:10.1177/1077801212460754

Enander, V. (2011). Violent women? The challenge of women's violence in intimate heterosexual relationships to feminist analyses of partner violence. NORA-Nordic Journal of Feminist and Gender Research, 19(2), 105-123. doi:10.1080/08038740.201 1.567999

Falcke, D., Oliveira, D. Z. Rosa, L. W. \& Bentancur, M. (2009). Violência conjugal: Um fenômeno interacional. Contextos Clínicos, 2(2). 81-90. doi:10.4013/ ctc. 2009.22 .02

Psico-USF, Bragança Paulista, v. 22, n. 3, p. 401-412, set./ dez. 2017 
Fincham, F. D., Cui, M., Gordon, M., \& Ueno, K. (2013). What comes before why: Specifying the phenomenon of intimate partner violence. Journal of Marriage and Family, 75(2), 319-324. doi:10.1111/ jomf.12000

Fortin, I., Guay, S., Lavoie, V., Boisvert, J. M., \& Beaudry, M. (2012). Intimate partner violence and psychological distress among young couples: Analysis of the moderating effect of social support. Journal of Family Violence, 27(1), 63-73. doi:10.1007/ s10896-011-9402-4

Gerstenberger, C. B., \& Williams, K. R. (2012). Gender and intimate partner violence: Does dual arrest reveal gender symmetry or asymmetry? Journal of Interpersonal Violence, 28(8) 1561-1578. doi:10.1177/0886260512468325

Goicolea, I., Öhman, A., Torres, M. S., Morras, I., \& Edin, K. (2012). Condemning violence without rejecting sexism? Exploring how young men understand intimate partner violence in Ecuador. Global Health Action, 5, 18049. doi:10.3402/gha. v5i0.18049

Gomes, N. P., Diniz, N. M. F., Araújo, A. J. de S., \& Coelho, T. M. de F. (2007). Compreendendo a violência doméstica a partir das categorias gênero e geração. Acta Paulista de Enfermagem, 20(4), 504-508. Retrieved from: http://www.scielo.br/pdf/ape/ v20n4/19.pdf

Gómez, J. L. G., \& Montesino, M. L. C. (2014). Prevalence of psychological and physical intimate partner aggression in Madrid (Spain): A dyadic analysis. Psicothema, 26(3), 343-348. doi:10.7334/ psioothema2013.262

Guedes, R. N., da Silva, A. T. M. C., \& Coelho, E. D. A. C. (2009). Violência conjugal: Problematizando a opressão das mulheres vitimizadas sob olhar de gênero. Revista Eletrônica de Enfermagem, 9(2), 362378. doi:10.1590/S1414-81452009000300024

Hamby, S. (2014). Intimate partner and sexual violence research scientific progress, scientific challenges, and gender. Trauma, Violence, \& Abuse, 15(3), 149158. doi: $10.1177 / 1524838014520723$

Hamby, S. (2015). A scientific answer to a scientific question: The gender debate on intimate partner violence. Trauma, Violence, \& Abuse, 1-10. doi:10.1177/1524838015596963
Hamby, S., \& Turner, H. (2013). Measuring teen dating violence in males and females: Insights from the national survey of children's exposure to violence. Psychology of Violence, 3(4), 323-339. doi:10.1037/ a0029706

Hans, J. D., Hardesty, J. L., Haselschwerdt, M. L., \& Frey, L. M. (2014). The effects of domestic violence allegations on custody evaluators' recommendations. Journal of Family Psychology, 28(6), 957-966. doi:10.1037/fam0000025

Jaquier, V., \& Sullivan, T. P. (2014). Fear of past abusive partner(s) impacts current posttraumatic stress among women experiencing partner violence. Violence against Women, 20(2), 208-227. doi:10.1177/1077801214525802

Johnson, M. P. (2010). Langhinrichsen-Rohling's confirmation of the feminist analysis of intimate partner violence: Comment on "Controversies involving gender and intimate partner violence in the United States". Sex Roles, 62(3-4), 212-219. doi:10.1007/ s11199-009-9697-2

Johnson, M. P., Leone, J. M., \& Xu, Y. (2014). Intimate terrorism and situational couple violence in general surveys ex-spouses required. Violence against Women, 20(2), 186-207. doi:10.1177/1077801214521324

Keating, B. (2015). Violence against women: A disciplinary debate and challenge. The Sociological Quarterly, 56(1), 108-124. doi:10.1111/tsq.12075

Krishnan, S., Vohra, D., De Walque, D., Medlin, C., Nathan, R., \& Dow, W. H. (2012). Tanzanian couples' perspectives on gender equity, relationship power, and intimate partner violence: Findings from the RESPECT study. AIDS Research and Treatment, 2012, 1-9. doi:10.1155/2012/187890

Lamoglia, C. V. A., \& Minayo, M. C. de S. (2009). Violência conjugal, um problema social e de saúde pública: Estudo em uma delegacia do interior do Estado do Rio de Janeiro. Ciência \& Saúde Coletiva, 14(2), 595604. doi:10.1590/S1413-81232009000200028

Langhinrichsen-Rohling, J. (2010). Controversies involving gender and intimate partner violence in the United States. Sex Roles, 62(3-4), 179-193. doi:10.1007/s11199-009-9628-2

Lee, M., Stefani, K. M., \& Park, E-C. (2014). Genderspecific differences in risk for intimate partner 
violence in South Korea. BMC Public Health, 14(415), 1-10. doi:10.1186/1471-2458-14-415

Lehmann, P., Simmons, C. A., \& Pillai, V. K. (2012). The validation of the Checklist of Controlling Behaviors (CCB): Assessing coercive control in abusive relationships. Violence against Women, 18(8), 913-933. doi:10.1177/1077801212456522

Leonard, K. E., Winters, J. J., Kearns-Bodkin, J. N., Homish, G. G., \& Kubiak, A. J. (2014). Dyadic patterns of intimate partner violence in early marriage. Psychology of Violence, 4(4), 384-398. doi:10.1037/ a0037483

Lövestad, S., \& Krantz, G. (2012). Men's and women's exposure and perpetration of partner violence: An epidemiological study from Sweden. BMC Public Health, 12(1), 945. doi:10.1186/1471-2458-12-945

Marshall, A. D., Jones, D. E., \& Feinberg, M. E. (2011). Enduring vulnerabilities, relationship attributions, and couple conflict: An integrative model of the occurrence and frequency of intimate partner violence. Journal of Family Psychology, 25(5), 709-718. doi:10.1037/a0025279

Mayorga, C., Coura, A., Miralles, N., \& Cunha, V. M. (2013). As críticas ao gênero e a pluralização do feminismo: Colonialismo, racismo e política heterossexual. Estudos Feministas, 21(2), 463-484. doi:10.1590/S0104-026X2013000200003

Melander, L. A., Noel, H., \& Tyler, K. A. (2010). Bidirectional, unidirectional, and nonviolence: A comparison of the predictors among partnered young adults. Violence and Victims, 25(5), 617-630. doi:10.1891/0886-6708.25.5.617

Mendes, K. D. S., Silveira, R. C. D. C. P., \& Galvão, C. M. (2008). Revisão integrativa: Método de pesquisa para a incorporação de evidências na saúde e na enfermagem. Texto \& Contexto Enfermagem, 17(4), 758-764. doi:10.1590/S0104-07072008000400018

Messinger, A. M. (2011). Invisible victims: Same-sex IPV in the national violence against women survey. Journal of Interpersonal Violence, 26(11), 2228-2243. doi:10.1177/0886260510383023

Messinger, A. M., Fry, D. A., Rickert, V. I., Catallozzi, M., \& Davidson, L. L. (2014). Extending Johnson's intimate partner violence typology lessons from an adolescent sample. Violence against Women, 20(8), 948-971. doi:10.1177/1077801214546907
Miller, L. E., Cater, A. K., Howell, K. H., \& GrahamBermann, S. A. (2014). Perpetration patterns and environmental contexts of IPV in Sweden: Relationships with adult mental health. Child Abuse \& Neglect, 38(1), 147-158. doi:10.1016/j. chiabu.2013.10.023

Moraes, C. L., Hasselmann, M. H., \& Reichenheim, M. E. (2002). Adaptação transcultural para o português do instrumento "Revised Conflict Tactics Scales (CTS2)" utilizado para identificar violência entre casais. Cadernos de Saúde Pública, 18(1), 163176. doi:10.1590/s0102-311x2002000100017

Myhill, A. (2015). Measuring coercive control: What can we learn from national population surveys? Violence Against Women, 21(3), 355-375. doi:10.1177/1077801214568032

Nowinski, S. N., \& Bowen, E. (2011). Partner violence against heterosexual and gay men: Prevalence and correlates. Aggression and Violent Behavior, 17(1), 3652. doi:10.1016/j.avb.2011.09.005

Nybergh, L., Taft, C., \& Krantz, G. (2012). Psychometric properties of the WHO Violence against Women instrument in a male population-based sample in Sweden. BMJ Open, 2(6), e002055. doi:10.1136/ bmjopen-2012-002055

Nybergh, L., Taft, C., \& Krantz, G. (2013). Psychometric properties of the WHO Violence against Women instrument in a female population-based sample in Sweden: A cross-sectional survey. BMJ Open, 3(5), e002053. doi:10.1186/1471-2458-13-845

Oliveira, D. C. D., \& Souza, L. D. (2006). Gênero e violência conjugal: Concepções de psicólogos. Estudos e Pesquisas em Psicologia, 6(2), 34-50. Retrieved from: http://www.revispsi.uerj.br/v6n2/artigos/pdf/ v6n2a04.pdf

Pazo, C. G., \& Aguiar, A. C. (2012). Sentidos da violência conjugal: Análise do banco de dados de um serviço telefônico anônimo. Revista de Saúde Coletiva, 22(1), 253-273. doi:10.1590/S0103-73312012000100014

Post, L. A., Mezey, N. J., Maxwell, C. D., \& Rhodes, K. R. (2011). Using capture-recapture to estimate the prevalence of intimate partner violence: The gender symmetry debate. International Journal of Science in Society, 2(2), 223-235. Disponível: http://ijy. cgpublisher.com/product/pub.187/prod.115 
Razera, J., Mosmann, C. P., \& Falcke, D. (2016). The interface between quality and violence in marital relationships. Paidéia, 26(63), 71-79. doi 10.1590/1982-43272663201609

Renner, L. M., Habib, L., Stromquist, A. M., \& PeekAsa, C. (2014). The association of intimate partner violence and depressive symptoms in a cohort of rural couples. The Journal of Rural Health, 30(1), 5058. doi:10.1111/jrh.12026

Santos, C. M., \& Izumino, W. P. (2005). Violência contra as mulheres e violência de gênero: Notas sobre estudos feministas no Brasil. Estudios Interdisciplinarios de América Latina y El Caribe, 16(1), 148-164. Retrieved from: http://www.nevusp.org/downloads/down083.pdf

Selic, P., Svab, I., \& Gucek, N. K. (2014). A crosssectional study identifying the pattern of factors related to psychological intimate partner violence exposure in Slovenian family practice attendees: What hurt them the most. BMC Public Health, 14(1), 223. doi:10.1186/1471-2458-14-223

Sillito, C. (2012). Gendered physical \& emotional health consequences of situational couple violence for heterosexual married \& cohabiting couples. Feminist Criminology, 7(4) 255-281. doi:10.1177/1557085111431695

Simmons, C. A., Farrar, M., Frazer, K., \& Thompson, M. J. (2011). From the voices of women: Facilitating survivor access to IPV services. Violence against Women, 17(10) 1226-1243. doi:10.1177/1077801211424476

Stark, E. (2010). Do violent acts equal abuse? Resolving the gender parity/asymmetry dilemma. Sex Roles, 62(3-4), 201-211. doi: 10.1007/s11199-009-9717-2

Straus, M. A. (2008). Dominance and symmetry in partner violence by male and female university in 32 nations. Children and Youth Services Review, 30, 252275. doi:10.1016/j.childyouth.2007.10.004

Straus, M. A. (2012). Blaming the messenger for the bad news about partner violence by women: The methodological, theoretical, and value basis of the purported invalidity of the Conflict Tactics Scales. Behavioral Sciences \& The Law, 30(5), 538-556. doi:10.1002/bsl.2023

Sullivan, T. P., Titus, J. A., Holt, L. J., Swan, S. C., Fisher, B. S., \& Snow, D. L. (2010). Does the inclusion criterion of women's aggression as opposed to their victimization result in samples that differ on key dimensions of intimate partner violence? Violence against Women, 16(1), 84-98. doi:10.1177/1077801209353575

Tanha, M., Beck, C. J., Figueredo, A. J., \& Raghavan, C. (2009). Sex differences in intimate partner violence and the use of coercive control as a motivational factor for intimate partner violence. Journal of Interpersonal Violence, 25(10) 1836-1854. doi:10.1177/0886260509354501

Umubyeyi, A., Mogren, I., Ntaganira, J., \& Krantz, G. (2014). Women are considerably more exposed to intimate partner violence than men in Rwanda: Results from a population-based, crosssectional study. BMC Women's Health, 14(1), 99. doi:10.1186/1472-6874-14-99

Volpe, E. M., Hardie, T. L., \& Cerulli, C. (2012). Associations among depressive symptoms, dating violence, and relationship power in urban, adolescent girls. Journal of Obstetric, Gynecologic, \& Neonatal Nursing, 41(4), 506-518. doi:10.1111/j.1552-6909.2012.01384.x

Walsh, Z., Swogger, M. T., O'Connor, B. P., Chatav Schonbrun, Y., Shea, M. T., \& Stuart, G. L. (2010). Subtypes of partner violence perpetrators among male and female psychiatric patients. Journal of Abnormal Psychology, 119(3), 563-574. doi:10.1037/ a0019858

Whitaker, M. P. (2013). Centrality of control-seeking in men's intimate partner violence perpetration. Prevention Science, 14(5), 513-523. doi:10.1007/ s11121-012-0332-z

Williams, S. L., \& Frieze, I. H. (2005). Patterns of violent relationships, psychological distress, and marital satisfaction in a national sample of men and women. Sex Roles, 52(11-12), 771-784. doi:10.1007/ s11199-005-4198-4

Winstok, Z. (2013). From a static to a dynamic approach to the study of partner violence. Sex Roles, 69(3-4), 193-204. doi:10.1007/s11199-013-0278-z

Winstok, Z. (2015). Critical review of Hamby's (2014) article titled "Intimate partner and sexual violence research, scientific progress, scientific challenges, and gender". Trauma, Violence, \& Abuse, 1-11. doi:10.1177/1524838015596962 
Zanoni, L., Warburton, W., Bussey, K., \& McMaugh, A. (2014). Child protection fathers' experiences of childhood, intimate partner violence and parenting. Children and Youth Services Review, 46, 91-102. doi:10.1016/j.childyouth.2014.08.009

Zoltowski, A. P. C., Costa, A. B., Teixeira, M. A. P., \& Koller, S. H. (2014). Qualidade metodológica das revisões sistemáticas em periódicos de psicologia brasileiros. Psicologia: Teoria e Pesquisa, 30(1), 97-104. doi:10.1590/S0102-37722014000100012

Recebido em: 18/02/2016 Reformulado em: 01/05/2016 Aprovado em: 09/05/2016

Sobre os autores:

Josiane Razera is a psychologist and holds a Lato Sensu graduate Degree in Marriage and Family Dynamics from Faculdade Meridional (IMED). PhaD and MSc in Clinical Psychology (Universidade do Vale dos Sinos -UNISINOS), with a CAPES/ PROSUP Scholarship. Professor of Psychology at Faculdade Meridional (IMED).

E-mail: josianerazera@yahoo.com.br

Icaro Bonamigo Gaspodini is a psychologist (Faculdade Meridional - IMED), PhD and MSc in Clinical Psychology (Universidade do Vale dos Sinos - UNISINOS), with a CAPES/ PROSUP Scholarship. Professor of Psychology at Faculdade Meridional (IMED).

E-mail: icaroicaro@gmail.com

Denise Falcke is a psychologist and holds a PhD from Pontifícia Universidade Católica do Rio Grande do Sul (PUCRS). Professor of Psychology at the Research Graduate Program in Clinical Psychology at Universidade do Vale do Rio dos Sinos (UNISINOS).

E-mail:dfalcke@unisinos.br

\section{Contato com os autores:}

Faculdade Meridional - IMED

Rua Senador Pinheiro, 304 - Vila Rodrigues

Passo Fundo-RS, Brasil

CEP: 99070-220 